\title{
Stress and coping in a sample of medical students in Brazil
}

\author{
Ana Margareth Siqueira Bassolsi,2, Bruna Brasil Carneiro³, Guilherme Correa Guimarães3, \\ Lucas Mestre Seiki Okabayashi ${ }^{3}$, Felipe Gutierrez Carvalho 3 , Anais Back da Silva 3 , \\ Gabriela Neubarth Cortes ${ }^{3}$, Luis Augusto Paim Rohde ${ }^{1,2}$, Claudio Laks Eizirik1,4
}

${ }^{1}$ Department of Psychiatry, Universidade Federal do Rio Grande do Sul (UFRGS), Porto Alegre, RS, Brazil.

2 Division of Child and Adolescent Psychiatry, Hospital de Clínicas de Porto Alegre (HCPA), UFRGS, Porto Alegre, RS, Brazil. 3 UFRGS, Porto Alegre, RS, Brazil.

${ }_{4}^{4}$ Division of Psychiatry, HCPA, UFRGS, Porto Alegre, RS, Brazil.

Received: 6/14/2014 - Accepted: 1/9/2015

DOI: 10.1590/0101-60830000000038

\begin{abstract}
Background: Medical training is a stressing situation, making medical students vulnerable to psychiatric disorders, such as depression and anxiety. Objective: The study aimed to assess the prevalence of stress and coping in students of a public medical school in Brazil, comparing the groups from the first and sixth years of training. Methods: Through a cross-sectional, observational study, a sample of 232 first and sixth-year regularly registered medical students has been evaluated. Students filled a socio-demographic questionnaire, the Lipp Inventory of Stress Symptoms (ISSL), and the Coping Strategies Inventory (CSI). Results: From the total sample of 232 students, 110 were first-year students and 122 sixth-year students. Stress symptoms were significantly higher in first-year students (49.1\%) than in the sixth-year group $(33.6 \% ; p=0.018)$. Variables significantly associated with stress were: year of the training ( $1^{\text {st }}$ year $>6^{\text {th }}$ year), income (lower $>$ higher income), satisfaction with the training (dissatisfied > satisfied) and the use of escape/avoidance copying strategy (positive association). Discussion: Considering the higher stress symptoms among first-year medical students and the positive association of the escape/avoidance copying strategy with stress, strategies must be developed to enable students starting medical school to be better at coping with this stressful situations.
\end{abstract}

Bassols AMS et al. / Arch Clin Psychiatry. 2015;42(1):1-5

Keywords: Students, medical, psychological stress, coping behavior, adaptation, psychological.

\section{Introduction}

Medical school is recognized as a stress factor that has a great impact on the life and health of undergraduates ${ }^{1,2}$. In the literature, depressive symptoms, like slowness of thought, difficulty in concentrating and indecisiveness, are also frequent in samples of university student and have been known to jeopardize academic development ${ }^{3-7}$; their presence is associated with perfectionism and with the constant stress this group is subjected 3,8 .

Since the XVIIth Century, the term stress began to be used in English, meaning "affliction", "adversity" 9 . Nowadays, the term stress designates a process in which the body reacts through physical and/or psychological components, which can result in physical and mental problems. Stress is also understood as a state of tension causing a disruption in the homeostasis of the individual, since, even before an external stressor, the subject may respond in different ways, according to their individual characteristics ${ }^{10}$. It is known that severe exposure to stress can lead to reduced self-esteem and low academic performance, due to decreased attention, concentration and loss of decision taking ability ${ }^{11,12}$. In addition, it can lead to dehumanization in contact with the patient ${ }^{13,14}$.

Stress is very common in conflictive or major demanding situations, such as training to become a medical doctor. Among the socioeducational factors that contribute to intensifying stress, is the great amount of information to be assimilated during the medical course; the pressure resulting from constant evaluations; the developmental period that the majority of students are in during the Medical School (the transition from adolescence to adulthood); a higher degree of curricular requirements; interaction with patients and changes in lifestyle among others ${ }^{15,16}$.

Although the research focused on university students has gained more space in recent decades ${ }^{17}$, Brazilian studies about symptoms of stress and burnout within this group are still scarce, as referred by Baldassin ${ }^{18}$.
The term coping refers to a complex process that is being used in the sense of "ways of dealing with", "confrontation strategies" or "mechanisms commonly used by individuals to cope with stress"19. The different ways in which the individual adapts to adverse circumstances, as well as the efforts made by the people in order to cope with chronic or acute stressful situations, have been the object of study during several decades ${ }^{20}$. Coping, under the situational perspective, is a cognitive and behavioral process that is modified as a function of time and the stress situation in which the individual is involved. Therefore, the effectiveness and adaptability of coping strategies are not determined a priori, but according to a person, the type of situation, the time and the results of their use ${ }^{21}$. In contrast, according to the dispositional approach, individual differences can influence coping responses based on the assumption of certain stability in its manifestations, determining the use of preferential strategies ${ }^{22}$.

In this study, we understand coping as a response to stress, a model defined by Folkman and Lazarus ${ }^{23}$, who identify two main types of coping, centered on the problem and centered on the emotion. Although both are linked to the perception of control, they differ in that the former is related to the effort to act on the situation that gave rise to stress, trying to change it, while the second consists in the regulation of the emotional state that is associated with stress or is the result of a stressful event. According to this theory, most people employ about eight coping strategies in all stressful events: confrontation, withdrawal, self-control, social support, escape/avoidance, accepting responsibility, problem solving and positive reappraisal.

For these authors, coping is a process or interaction that occurs between the individual and the environment; its function is managing the stressful situation processes. It presupposes the notion of evaluation, i.e., how the phenomenon is perceived, interpreted and cognitively represented in the mind of the individual, constituting a mobilization of cognitive and behavioral efforts to manage (reduce, minimize or tolerate) the internal or external demands that arise from its interaction with the environment ${ }^{24}$. 
This research aimed to evaluate prevalence and levels of stress symptoms, and coping strategies used to deal with stress in students at the entry and exit of the Medical School in a public University, in southern Brazil.

\section{Methods}

\section{Sample}

This is a cross-sectional study that evaluated students of both sexes at the first and sixth-year of the medical course at one of the Public University (Federal University of Rio Grande do Sul - UFRGS) in the capital of the southernmost state of Brazil. The study was approved by the Ethics Committee of the Hospital de Clinicas de Porto Alegre (Protocol No. 09-444).

\section{Procedures}

Trained research assistants performed the data collection. The first year students filled the forms in their classrooms in between two disciplines (May 2010, half-way through the semester); the $6^{\text {th }}$ year data was collected at the hospital at different moments, since no discipline congregating all students exists at this stage of the course. As expected, data collection was more difficult for sixth-year students, making the period longer for this group. The subjects responded anonymously and voluntarily to the survey instruments after signing the Informed Consent form.

\section{Instruments}

a) The socio-demographic and health questionnaire was constructed for this study included data on gender, family and personal income, where the student lived (with his/her family or in off-campus communal housing, participation in leisure activities, use of alcohol and drugs, medication and the presence of some physical illness.

b) Inventory of Stress Symptoms for Adults, Lipp (ISSL) to rate the degree of stress ${ }^{25}$. The ISSL was developed and validated for use in Brazil, presenting adequate internal consistency $(\alpha=0.91)^{25}$. It is composed by four dimensions $(\mathrm{Q})$ that divide temporally symptoms into the last 24 hours (Q1 - 15 symptoms; the alert phase), last week (Q2 - until 9 symptoms; the resistance) Q3 (near-exhaustion phase above 10 symptoms) and last month (Q4 - 23 symptoms; exhaustion phase or Burnout).

The symptoms are divided into physical and psychological dimensions, corresponding to the most frequent manifestations of stress $^{9,28}$. In ISSL, a positive diagnosis of stress is based on the sum of the symptoms of each frame of the inventory (Q1 $>6$; Q2 $>3$ or Q3 > 9; Q4 > 8), allowing data to indicate not only that the person has stress, but also the phase where symptoms are predominant ${ }^{25}$.

c) Coping Strategies Inventory adapted to the Brazilian Portuguese language by Savóia et al. to assess the strategies used to deal with stressful situations ${ }^{26}$, like being a medical student. The Cronbach's Alphas for the eight sub-scales were between 0.65 and 0.80 . The eight types of coping identified by the inventory also seem to be appropriate.

\section{Data analyses}

The sample size calculation assuming differences in the order of $20 \%$ in the total scores of the instruments between the two groups, considering the power of $80 \%$ and a significance level of $0.5 \%$ indicated a sample of approximately 103 students in each group. The first objective of the analysis was to evaluate if the groups were statistically comparable. These analyses were conducted through the chi-square test for categorical variables and the $T$ test for continuous variables.

Simple Poisson bivariate regression analyses - with adjustment for robust variances - were performed, considering stress as an outcome. Variables with " $\mathrm{p}$ " below 0.2 in bivariate analyses either when comparing first and sixth-year students or in Simple Poisson bivariate regression analyses were included in the final model. The IBM SPSS, version ${ }^{18}$ was used for the analysis.

\section{Results}

Overall, 149 students were enrolled in the first year of the UFRGS School of Medicine in 2010, and 195 students were enrolled in the sixth year, in 2010 and 2011, according to a list provided by the Graduation Committee of the Medical School (COMGRAD). Twohundred and thirty two questionnaires were collected, 110 from the first year course (73.8\% of those enrolled) and 122 among the sixth year students (62.6\% of the students enrolled). The following variables were significantly different between groups: family income, performing a paid activity, use of alcohol/drugs and use of medication (Table 1).

Table 1. Socio-demographic and health data

\begin{tabular}{|c|c|c|c|c|}
\hline Variables & $\begin{array}{c}1^{\circ} \text { year } \\
\text { Frequency }(\%)\end{array}$ & $\begin{array}{c}6^{0} \text { year } \\
\text { Frequency }(\%)\end{array}$ & \begin{tabular}{c|} 
Total \\
Frequency $(\%)$
\end{tabular} & $p$ \\
\hline Number of students & $110(47.4)$ & $122(52,6)$ & 232 & - \\
\hline Age $^{*}$ & 20.7 (SD 2.6) & 25.34 (SD 2.7) & 23.1 (SD 3.2) & - \\
\hline Male students** & $62(56.4 \%)$ & $55(45.1 \%)$ & $117(50.4 \%)$ & 0.113 \\
\hline Leisure time ${ }^{* *}$ & $94(87 \%)$ & $109(90.1 \%)$ & $203(88.6 \%)$ & 0.605 \\
\hline Live with their family** & $65(59.6 \%)$ & $56(45.9 \%)$ & $121(52.4 \%)$ & 0.051 \\
\hline $\begin{array}{l}\text { Living in communal } \\
\text { off-campus housing }{ }^{* *}\end{array}$ & $8(7.3 \%)$ & $8(6.6 \%)$ & $16(6.9 \%)$ & $>0.999$ \\
\hline $\begin{array}{l}\text { Family income up to } \\
\text { U\$ } 1.749,27^{+* *}\end{array}$ & $43(40.2 \%)$ & $32(26.7 \%)$ & $75(33.0 \%)$ & 0.043 \\
\hline Perform paid activity** & $11(10.0 \%)$ & $43(35.5 \%)$ & $54(23.4 \%)$ & $<0.001$ \\
\hline Coffee intake ${ }^{* *}$ & $80(74.1 \%)$ & $101(82.8 \%)$ & $181(78.8 \%)$ & 0.147 \\
\hline Drug and alcohol use & $38(35.2 \%)$ & $66(54.5 \%)$ & $104(45.4 \%)$ & 0.005 \\
\hline Cigarette smoking** & $5(4.5 \%)$ & $5(4.2 \%)$ & $10(4.4 \%)$ & $>0.999$ \\
\hline $\begin{array}{l}\text { Presence of some } \\
\text { illness** }\end{array}$ & $28(25.9 \%)$ & $42(35.0 \%)$ & $70(30.7 \%)$ & 0.180 \\
\hline Use of medication ${ }^{* *}$ & $36(33.6 \%)$ & $59(51.3 \%)$ & $95(42.8 \%)$ & 0.012 \\
\hline Low satisfaction & $27(24.5 \%)$ & $27(22.1 \%)$ & $54(23.3 \%)$ & 0.780 \\
\hline
\end{tabular}

* Averages and Standard Deviation (SD) calculated through the Student's $t$ test.

** Variables compared through the Pearson Chi-square with continuity correction.

${ }^{+}$Amount equivalent to $\mathrm{R} \$ 5.000,00$ at the time of data collection.

In the sample, $40.95 \%$ of the subjects (95 students) presented stress symptoms. Among them 2 (2.1\%) were in the alert phase, 89 $(93.7 \%)$ in the resistance phase and $4(4.2 \%)$ at the almost exhaustion phase. The prevalence of stressed students in the first year was $49.1 \%$ $[(\mathrm{n}=54) ; 2$ where in the alert phase $(3.7 \%)$, resistance/endurance 51 (94.4\%) and almost exhaustion $1(1.9 \%)]$ and $33.6 \%$ in the sixth-year students [within respective phases: $\mathrm{n}=41 ; 0(0,0 \%), 38(92.7 \%)$ and 3 (7.3\%)]. Thus, stress symptoms were significantly higher in first-year students $(49.1 \%)$ than in the sixth-year group (33.6\%), $\mathrm{p}=0.018$. No student of the sample scored in the burnout level.

In bivariate analyses, the following factors were significantly associated with stress: age, gender, year of the course, family income, bear a disease, using some sort of medication and satisfaction with the course (Table 2 ). The variables that remain statistically significant after the control through multivariate analysis were year of the course, income, satisfaction with the course (Table 2). Age was not included in the multivariate model, since it has, as expected, a huge collinearity with year of course. The bivariate analysis of coping strategies having stress as an outcome variable is shown in table 2 . In the multivariate model, only escape/avoidance strategy was significantly higher in stressed students. 
Table 2. Table of bivariate analysis and Poisson's Regression with stress as outcome

\begin{tabular}{|c|c|c|c|c|c|}
\hline & \multirow[b]{2}{*}{$\%$ of stress } & \multicolumn{2}{|c|}{ Bivariate analysis } & \multicolumn{2}{|c|}{ Poisson's regression } \\
\hline & & $\begin{array}{l}\text { Relative risk brut } \\
\text { (I.C. } 95 \% \text { ) }\end{array}$ & $p$ & $\begin{array}{c}\text { Relative risk } \\
\text { adjusted (I.C. 95\%) }\end{array}$ & $\mathrm{p}$ (adjus.) \\
\hline \multicolumn{6}{|l|}{ Gender } \\
\hline $\begin{array}{l}\text { Female } \\
\text { Male }\end{array}$ & $\begin{array}{l}60(52.2 \%) \\
35(29.9 \%)\end{array}$ & $\begin{array}{c}1.74(1.26-2.42) \\
1.00 \\
\end{array}$ & 0.001 & $\begin{array}{c}1.30(0.925-1.82) \\
1.00 \\
\end{array}$ & 0.131 \\
\hline \multicolumn{6}{|l|}{ Age } \\
\hline $\begin{array}{l}\text { Lower than median (less than } 23 \text { years) } \\
\text { Higher than median (more than } 23 \text { years) }\end{array}$ & $\begin{array}{l}59(48.4 \%) \\
36(32.7 \%)\end{array}$ & $\begin{array}{c}1.48(1.07-2.04) \\
1.00\end{array}$ & 0.018 & & \\
\hline \multicolumn{6}{|l|}{ Course year } \\
\hline $\begin{array}{l}\text { First year } \\
\text { Sixth year }\end{array}$ & $\begin{array}{l}54(49.1 \%) \\
41(33.6 \%) \\
\end{array}$ & $\begin{array}{c}1.46(1.07-2.00) \\
1.00\end{array}$ & 0.018 & $\begin{array}{c}1.48(1.07-2.05) \\
1.00 \\
\end{array}$ & 0.017 \\
\hline \multicolumn{6}{|l|}{ Leisure activities } \\
\hline $\begin{array}{l}\text { Practice leisure activities } \\
\text { Do not practice leisure activities }\end{array}$ & $\begin{array}{l}84(41.4 \%) \\
10(38.5 \%)\end{array}$ & $\begin{array}{c}1.08(0.64-1.80) \\
1.00\end{array}$ & 0.780 & & \\
\hline \multicolumn{6}{|l|}{ Living with their family } \\
\hline $\begin{array}{l}\text { Live with their family } \\
\text { Do not live with their family }\end{array}$ & $\begin{array}{l}46(38.0 \%) \\
49(44.5 \%) \\
\end{array}$ & $\begin{array}{c}0.85(0.63-1.16) \\
1.00 \\
\end{array}$ & 0.314 & $\begin{array}{c}0.93(0.69-1.27) \\
1.00 \\
\end{array}$ & 0.668 \\
\hline \multicolumn{6}{|l|}{ Living in communal off-campus housing* } \\
\hline $\begin{array}{l}\text { Live in a republic } \\
\text { Do not live in a republic }\end{array}$ & $\begin{array}{l}8(50.0 \%) \\
87(40.3 \%)\end{array}$ & $\begin{array}{c}1.24(0.74-2.08) \\
1.00\end{array}$ & 0.412 & & \\
\hline \multicolumn{6}{|l|}{ Family income } \\
\hline $\begin{array}{l}\text { Up to 2,915.45 dollars' } \\
\text { More than 2,915.45 dollars }\end{array}$ & $\begin{array}{l}38(50.7 \%) \\
53(34.9 \%) \\
\end{array}$ & $\begin{array}{c}1.45(1.06-1.98) \\
1.00 \\
\end{array}$ & 0.019 & $\begin{array}{c}1.40(1.04-1.89) \\
1.00 \\
\end{array}$ & 0.027 \\
\hline \multicolumn{6}{|l|}{ Performing a paid activity } \\
\hline $\begin{array}{l}\text { Perform paid activity } \\
\text { Do not perform a paid activity }\end{array}$ & $\begin{array}{l}18(33.3 \%) \\
77(43.5 \%) \\
\end{array}$ & $\begin{array}{c}0.77(0.51-1.16) \\
1.00 \\
\end{array}$ & 0.206 & $\begin{array}{c}0.97(0.61-1.54) \\
1.00\end{array}$ & 0.885 \\
\hline \multicolumn{6}{|l|}{ Coffee intake } \\
\hline $\begin{array}{l}\text { Drink coffee } \\
\text { Do not drink coffee }\end{array}$ & $\begin{array}{l}74(40.9 \%) \\
20(40.8 \%)\end{array}$ & $\begin{array}{c}1.00(0.68-1.46) \\
1.00\end{array}$ & 0.993 & $\begin{array}{c}0.95(0.66-1.37) \\
1.00\end{array}$ & 0.780 \\
\hline \multicolumn{6}{|l|}{ Alcohol/Drug use } \\
\hline $\begin{array}{l}\text { Use alcohol/drug } \\
\text { Do not use alcohol/drug }\end{array}$ & $\begin{array}{l}38(36.5 \%) \\
56(44.8 \%) \\
\end{array}$ & $\begin{array}{c}0.82(0.59-1.12) \\
1.00 \\
\end{array}$ & 0.211 & $\begin{array}{c}0.94(0.69-1.28) \\
1.00\end{array}$ & 0.698 \\
\hline \multicolumn{6}{|l|}{ Cigarette smoking (tobacco) } \\
\hline $\begin{array}{l}\text { Smokers } \\
\text { Non-smokers }\end{array}$ & $\begin{array}{l}4(40.0 \%) \\
91(41.7 \%)\end{array}$ & $\begin{array}{c}0.96(0.44-2.08) \\
1.00\end{array}$ & 0.914 & & \\
\hline \multicolumn{6}{|l|}{ Illness bearer } \\
\hline $\begin{array}{l}\text { Bear an illness } \\
\text { Do not bear any illness }\end{array}$ & $\begin{array}{l}38(54.3 \%) \\
56(35.4 \%) \\
\end{array}$ & $\begin{array}{c}1.53(1.3-2.07) \\
1.00 \\
\end{array}$ & 0.005 & $\begin{array}{c}1.27(0.92-1.76) \\
1.00 \\
\end{array}$ & 0.147 \\
\hline \multicolumn{6}{|l|}{ Medication use } \\
\hline $\begin{array}{l}\text { Use medication } \\
\text { Do not use medication }\end{array}$ & $\begin{array}{l}49(51.6 \%) \\
46(36.2 \%)\end{array}$ & $\begin{array}{c}1.42(1.05-1.93) \\
1.00\end{array}$ & 0.022 & $\begin{array}{c}1.37(0.96-1.96) \\
1.00\end{array}$ & 0.084 \\
\hline \multicolumn{6}{|l|}{ Satisfaction with the course } \\
\hline $\begin{array}{l}\text { Dissatisfied } \\
\text { Satisfied }\end{array}$ & $\begin{array}{l}29(53.7 \%) \\
66(37.1 \%) \\
\end{array}$ & $\begin{array}{c}1.45(1.06-1.98) \\
1.00 \\
\end{array}$ & 0.020 & $\begin{array}{c}1.52(1.09-2.13) \\
1.00\end{array}$ & 0.014 \\
\hline \multicolumn{6}{|l|}{ Coping } \\
\hline Escape/avoidance & & $1.21(1.12-1.31)$ & 0.00 & $1.14(1.04-1.25)$ & 0.005 \\
\hline Social support & & $1.03(0.99-1.07)$ & 0.056 & $1.00(0.97-1.04)$ & 0.819 \\
\hline Confrontation & & $1.07(1.02-1.13)$ & 0.002 & $1.04(0.99-1.01)$ & 0.122 \\
\hline Self-control & & $0.99(0.93-1.04)$ & 0.616 & & \\
\hline Withdrawal/Detachment & & $1.02(0.98-1.07)$ & 0.317 & & \\
\hline Responsibility acceptance & & $1.04(1.00-1.08)$ & 0.036 & $1.00(0.96-1.04)$ & 0.918 \\
\hline Problem resolving & & $0.97(0.91-1.04)$ & 0.396 & & \\
\hline Positive reevaluation & & $0.99(0.97-1.03)$ & 0.881 & & \\
\hline
\end{tabular}

${ }^{\dagger}$ Amount equivalent to $\mathrm{R} \$ 5,000.00$ at the time of data collection.

\section{Discussion}

We found that the entrance in the Medical School was associated with higher stress than the final part of the course. In addition, the following variables were associated with stress in this sample of Medical students: year of the course, low income, satisfaction with the course and the use of escape/avoidance copying strategy.

The way students cope with stress may influence their adjustment to medical school and whether or not stress will detrimentally affect 
their quality of life. According Tempski, despite students reported that their quality of life in medical school is worse than in other contexts of their life, they evaluated it positively due they perceived sacrifices and difficulties of the program as necessary to become a doctor. Such dissatisfaction is related to the learning environment and the curriculum ${ }^{27}$.

The prevalence of stress symptoms found in the present study was not as high as the one found in previous studies ${ }^{17,28}$. No student of the sample scored in the burnout level, however, over $90 \%$ of the students independently of the year at Medical School scored their stress in the range compatible with the resistance phase. This level is sufficient for producing physical fatigue, attention and memory problems, insomnia, hypersensitivity and increased susceptibility to infectious diseases in addition to impairment of productivity ${ }^{29}$. Students at this level of stress might have an impaired efficiency, yielding less than expected, according to their capacity.

When tracing the profile of the groups, income was higher and performing a paid activity was more prevalent in the group of sixth graders, as expected. This scenario can be a result of carrying out activities such as research/extension and obtaining grants or even working "on duty shifts". Furthermore, the first-year group included students admitted under affirmative action policies at the time of data collection ( $20 \%$ of the total number of students), which might have contributed to a reduction in mean household income. According to research from Psychosomatic Medicine ${ }^{30}$, it's those in lower socioeconomic levels who experience greater levels of stress and experience more stress-related health problems, as well. Workers who have higher levels of job stress experience a greater incidence of the common cold, and call in sick more often. There has also been a documented link between high job stress and lower levels of mental health.

Our finding differs from previous results in other Brazilian studies ${ }^{15,16}$ in which stress was higher in the sixth-year group or increased in the middle of the course, when occurs the transition to the medical clinic with greater contact with patients. It is possible for students currently enrolled in the sixth grade has had a peak stress in the middle of the course, but we cannot confirm this hypothesis. Another aspect to consider is that their psychological development and greater adaptation to routines could have enabled a reduction of stress in these students.

The literature suggests a correlation between the degree of satisfaction of medical students and the level of involvement and engagement in curricular activities ${ }^{31,32}$. To this end, there has to be a good adequacy of the student to the university environment and acceptance of aspects as proposed by the course curriculum that will contribute to greater satisfaction and would possibly favor the reduction of stress factors. The report of greater satisfaction with the course being significantly higher in first year students raises the hypothesis that, in spite of anxiety being higher at the beginning of the course ${ }^{33}$, it is likely that the new condition of "freshman" and the interest in learning, favor satisfaction. In fact, after enrolment will be the quality of teaching and learning that contribute most to the student (in) satisfaction ${ }^{34,35}$. According to the literature, the dissatisfaction with the traditional academic curriculum in medical schools has increased dramatically, requiring evaluations of medical education and their impact on student's health and welfare processes ${ }^{10}$.

Regarding coping strategies, it is extremely relevant that stressed students from the Medical School use more escape-avoidance tactics than non-stressed students, even more considering that this is one of the most maladaptive coping styles. Moreover, this was the only copying mechanism significantly different between stressed and nonstressed students. Escape-avoidance coping involves disengaging or staying away from a stressful situation and its behavioral and cognitive/emotional consequences. Typical strategies of this copying stile in response to a stressful situation might encompass cognitive avoidance ("Refused to believe"). Avoidance coping causes anxiety to snowball because when people use avoidance coping they typically end up experiencing more of the very thing they were trying to escape ${ }^{36}$.
Some limitations of the present study should be taken into account. Because it is a cross sectional investigation, it is impossible to establish a temporal relationship between stress and year of the course, income, satisfaction with the course and the use of escape/ avoidance copying strategy. Besides, we used only self-report measures of stress. Our enrollment rate for sixth-year students was lower than the one for the first-year students, possibly due to facts such as higher work-load, the on-duty shift regime and having to study harder for the residency exams. The data collection for the first and sixth year groups was performed in different environments due to the reality of the students' activities during the course's program. While disciplines of the core curriculum take place in classrooms, in initial semesters, as the course advances, disciplines are mostly practical, making the students move around in different areas - even in different hospitals. Finally, the results refer to the sample of Medical Students at the Universidade Federal do Rio Grande do Sul (UFRGS). Generalizability to other Medical School students should be done cautiously. There are many coping inventories available in the literature, and the present study employed only one of them. Findings might be specific to this instrument. Furthermore, due to logistical issues, we could neither collect data simultaneously nor obtain data from the students who did not complete the study instruments.

\section{Conclusion}

Medical education exposes students to hospital reality since the first year of the course, causing insecurity among freshmen who must deal not only with illness situations but also face life and death dilemmas prematurely. It is possible that the knowledge acquired throughout the course; the maturity gained across time, the experience obtained through clinical practice and the coping methods used allow for better psychological conditions in the sixth year students to face similar problems to those they were confronted when entering medical school. In addition, they might develop some degree of resistance to stress by the end of the course. Possible interventions in order to avoid manifestations of stress and even burnout must be implemented early in the Medical Course. Our findings suggest that vulnerable students should be identified early in their first year and provided with additional support. In addition, information about effective coping strategies (i.e. active coping efforts) and ineffective means of dealing with stress (escape-avoidance efforts) and training in implementing more adaptive copying mechanisms to face stress might be helpful in preventing distress ${ }^{37}$. To conclude, we need interventions that help students cope with stress in a more mature way, to make a smooth transition from school to medical school, and also to adjust to different learning environments during the different phases of medical education.

\section{Acknowledgements}

This study was funded by Fundo de Incentivo à Pesquisa do Hospital de Clínicas de Porto Alegre (FIPE-HCPA).

The authors wish to thank Statistician Vania Naomi Hirakata for performing of analyses and database management and the students for their cooperation.

\section{Disclosure}

LAR has been on the speakers' bureau/advisory board and/or acted as consultant for Eli-Lilly, Janssen-Cilag, Novartis and Shire in the last three years. The ADHD and Juvenile Bipolar Disorder Outpatient Programs chaired by him received unrestricted educational and research support from the following pharmaceutical companies in the last three years: Eli-Lilly, Janssen-Cilag, Novartis, and Shire. The other authors report no conflicts of interest.

\section{References}

1. Prinz P, Hertrich K, Hirschfelder U, Zwaan M. Burnout, depression and depersonalization - Psychological factors and coping 
strategies in dental and medical students. GMS Z Med Ausbild. 2012;29(1):Doc 10.

2. Dahlin M, Joneborg N, Runeson B. Stress and depression among medical students: a cross-sectional study. Medical Education. 2005;39:594-604.

3. Amaral GF, Gomide LMP, Batista MP, Piccolo PP, Teles TBG, Oliveira PM, et al. Sintomas depressivos em acadêmicos de medicina da Universidade Federal de Goiás: um estudo de prevalência. Rev Psiquiatr Rio Gd Sul. 2008;30:124-30.

4. Murray CJ, Lopez AD. Alternative projections of mortality and disability by cause 1990-2020: Global Burden of Disease Study. Lancet. 1997;349:1498-504.

5. Baldassin S. Ansiedade e depressão no estudante de medicina: revisão de estudos brasileiros. Cadernos ABEM. 2010;6:19-26.

6. Yusoff MS, Abdul Rahim AF, Baba AA, Ismail SB, Mat Pa MN, Esa AR. Prevalence and associated factor of stress, anxiety and depression among prospective medical students. Asian JPsychiatr. 2012;6:128-33.

7. Barria ACR, Queiroz S, Nicastri S, Andrade AG. Comportamento do universitário da área de biológicas da Universidade de São Paulo, em relação ao uso de drogas. Rev Psiquiatr Clin (Sao Paulo). 2000;27:215-24.

8. Enns MW, Cox BJ, Sareen J, Freeman P. Adaptive and maladaptive perfectionism in medical students: a longitudinal investigation. Med Educ. 2001;35:1034-42.

9. Lipp MEN. Stress: conceitos básicos. In: Lipp, MEN (Org). Pesquisas sobre o stress no Brasil: saúde, ocupações, grupos de risco. 2 ed. Campinas: Papirus, 2001a, p. 17-31.

10. West CP, Shanafelt TD. The influence of personal and environmental factors on professionalism in medical education. BMC Medical Education. 2007;7:29.

11. Lipp MEN. O que eu tenho é stress? De onde ele vem? In: Lipp MEN (org.) O stress está dentro de você. 4.ed. São Paulo: Contexto, 2001b, p. 9-18.

12. Niemi PM, Vainiomaki PT. Medical students' academic distress, coping and achievement strategies during the pre-clinical years. Teach Learn Med. 1999;11:125-34.

13. Guthrie EA, Black D, Shaw CM, Hamilton J, Creed FH, Tomenson B. Embarking upon a medical career: psychological morbidity in first year medical students. Med Educ. 1995;29:337-4.

14. Dyrbye LN, Stanford Massie Jr F, Eacker A, Harper W, Power D, Durning SJ, et al. Relationship between burnout and professional conduct and attitudes among US medical students. JAMA. 2010;304:1173-80.

15. Aguiar SM, Vieira APGF, Vieira KMF, Aguiar SM, Nóbrega JO. Prevalência de sintomas de estresse nos estudantes de medicina. J Bras Psiquiatr. 2009;58:34-8.

16. Guimarães KBS. Estresse e a formação médica: implicações na saúde mental dos estudantes. Assis; 2005. Mestrado [Dissertação] - Universidade Estadual Paulista Júlio de Mesquita Filho, Unesp.

17. Dyrbye LN, Thomas MR, Shanafelt TD. Systematic review of depression, anxiety, and other indicators of psychological distress among U.S. and Canadian medical students. Acad Med. 2006;81(4):354-73.

18. Baldassin S. Anxiety and depression in medical students: a review of Brazilian studies. Cadernos ABEM. 2010;6:19-26.
19. Ramos SIV, Carvalho AJR. Nível de stress e estratégias de coping dos estudantes de $1^{\circ}$ ano do Ensino Universitário de Coimbra. Rev Interacções. 2007.

20. Suls J, David JP, Harvey JH. Personality and coping: three generations of research. J Pers. 1996;64:711-35.

21. Beresford BA. Resources and strategies: how parents cope with the care of disabled child. J Child Psychol Psychiatry. 1994;35:171-209.

22. Costa ES, Leal IP. Estratégias de coping em estudantes do Ensino Superior. Ana Psicol. 2006;24:189-99.

23. Folkman S, Lazarus RS. If it changes, it must be a process: a study of emotion and coping during three stages of a college examination. J Pers Soc Psychol. 1985;48:150-70.

24. Folkman S, Lazarus RS. An analysis of coping in a middle-aged community sample. J Health Soc Behav. 1980;21(3):219-39.

25. Lipp MEN. Inventário de sintomas de stress para adultos de lipp. 3.ed. São Paulo: Casa do Psicólogo; 2005.

26. Savóia MG, Santana PR, Meijas NP. Adaptação do inventário de estratégias de coping de Folkman e Lazarus para o português. Psicologia USP. 1996;7:183-201.

27. Tempski P, Bellodi PL, Paro HBMS, Enns SC, Martins MA, Schraiber LB. What do medical students think about their quality of life? A qualitative study. BMC Medical Education. 2012;12:106.

28. Aktekin M, Karaman T, Senol YY, Erdem S, Erengin H, Akaydin M. Anxiety, depression and stressful life events among medical students: a prospective study in Antalya, Turkey. Med Educ. 2001;35:12-7.

29. Santos AF, Alves Júnior A. Estresse e estratégias de enfrentamento em mestrandos de ciência de Saúde. Psicol Reflex Crit. 2007;20:104-13.

30. Cohen S, Doyle WJ, Baum A. Socioeconomic status is associated with stress hormones. Psychosomatic Medicine. 2006;68:414-20.

31. Bardagi MP, Paradiso AC. Trajetória acadêmica e satisfação com a escolha profissional de universitários em meio de curso. Rev Bras Orientac Prof (São Paulo). 2003;4:153-66.

32. Abrão CB, Coelho EP, Passos LBS. Prevalência de sintomas depressivos entre estudantes de medicina da Universidade Federal de Uberlândia. Rev Bras Educ Med. (Rio de Janeiro). 2008;32:315-23.

33. Bassols AM, Okabayashi LS, Silva AB, Carneiro BB, Feijó F, Guimarães GC, et al. First- and last-year medical students: is there a difference in the prevalence and intensity of anxiety and depressive symptoms? Rev Bras Psiquiatr. 2014;36(3):233-40.

34. Douglas J, Douglas A, Barnes B. Measuring student satisfaction at UK university. Quality Assurance in Education. 2006;14:251-67.

35. Clark DC, Zeldow PB. Vicissitudes of depressed mood during four years of medical school. JAMA. 1988;260:2521-7.

36. 36 . Boyes A. In: In Practice. Why Avoidance Coping is the Most Important Factor in Anxiety Avoidance coping causes anxiety to snowball. March 5, 2013.

37. Stewart SM, Betson C, Lam TH, Marshall IB, Lee PW, Wong CM. Predicting stress in first year medical students: a longitudinal study. Hong Kong. Med Educ. 1997;31(3):163-8. 